\title{
PENGARUH KONTRAK PSIKOLOGIS TERHADAP INTENSI KELUAR DENGAN KOMITMEN AFEKTIF SEBAGAI VARIABEL MEDIATOR
}

\author{
THE EFFECT OF PSYCHOLOGICAL CONTRACTS ON OUTSIDE INTENSION WITH AFECTIVE \\ COMMITMENTS AS MEDIATOR VARIABLES
}

\author{
Asri Raditya Wardhani") dan C. Budi Santoso ${ }^{* 1}$ \\ *) Departemen Manajemen, Fakultas Ekonomika dan Bisnis, Universitas Gadjah Mada \\ Jl. Sosio Humaniora No.1 Bulaksumur, Yogyakarta 55281
}

\begin{abstract}
This study aims to examine the negative effects of psychological contract to turnover intention and test the role of affective commitment as a mediating on the negative effects of psychological contract on turnover intention. A total of 214 questionnaires that can be processed in this study where samples are taken from hotel employees. Testing model in this research using hierarchical regression analysis method (hierarchical regression analysis). The results reported that psychological contract have a negative and significant influence on turnover intention. In addition, affective commitment is also reported to have a mediating role in the influence of psychological contract on turnover intention. In other words, the high level of employee psychological contract fulfillment can directly minimize the turnover intention and indirectly the psychological contract can minimize the turnover intention through affective commitment.
\end{abstract}

Keywords: psychological contract, turnover intention, affective commitment

\begin{abstract}
Abstrak: Penelitian ini bertujuan menguji pengaruh negatif kontrak psikologis terhadap intensi keluar dan menguji peran pemediasian komitmen afektif pada pengaruh negatif kontrak psikologis terhadap intensi keluar. Sebanyak 214 kuesioner yang dapat diolah dalam penelitian ini dimana sampel diambil dari karyawan hotel. Pengujian model dalam penelitian ini menggunakan metode analisis regresi berjenjang (hierarchical regression analysis). Hasil penelitian melaporkan bahwa kontrak psikologis memiliki pengaruh negatif dan signifikan terhadap intensi keluar. Selain itu, komitmen afektif juga dilaporkan memiliki peran sebagai pemediasi dalam pengaruh kontrak psikologis terhadap intensi keluar. Dengan kata lain, tingginya tingkat pemenuhan kontrak psikologis karyawan dapat secara langsung meminimalkan intensi keluar dan secara tidak langsung kontrak psikologis dapat meminimalkan intensi keluar melalui komitmen afektif.
\end{abstract}

Kata kunci: kontrak psikologis, intensi keluar, komitmen afektif

\footnotetext{
${ }^{1}$ Alamat Korespondensi:

Email: bsantoso@ugm.ac.id
} 


\section{PENDAHULUAN}

Pentingnya isu kontrak psikologis terbukti pada hasil survei yang dilakukan oleh Chartered Institute of Personel and Development (CIPD) bahwa keadaan positif dari kontrak psikologis berhubungan dengan tingginya tingkat kepuasaan kerja, komitmen dalam perusahaan, keamanan kerja, kepuasaan antara hubungan pengusaha dan pekerja, motivasi dan niat untuk tetap bertahan dalam perusahaan (Guest dan Conway, 2005). Sebanyak 90\% setuju bahwa kontrak psikologis adalah sebuah konsep yang berguna dan $36 \%$ mengatakan mereka menggunakannya untuk membantu mengelola hubungan kerja (Guest dan Conway, 2005).

Definisi kontrak psikologis adalah suatu kontrak informal tidak tertulis yang terdiri dari ekspektasi karyawan dan atasan mengenai hubungan kerja yang bersifat timbal balik sebagai balasan dari kontribusi kewajiban yang telah dilakukan (Robinson dan Rousseau, 1994; Rousseau, 1995). Sedangkan, pelanggaran kontrak psikologis merujuk pada tanggapan bahwa individu atau karyawan menerima kurang dari atau lebih sedikit dari apa yang sudah dijanjikan, atau bahkan tidak menerima sama sekali yang telah dijanjikan kepada mereka (Morrison dan Robinson, 1997).

Ketika karyawan percaya bahwa telah terjadi pelanggaran kontrak psikologis maka akan memengaruhi munculnya reaksi negatif, seperti rendahnya tingkat kinerja, rendahnya kepuasan kerja, dan menimbulkan niat untuk keluar organisasi (Suazo et al. 2009). Sebaliknya, keberhasilan organisasi dalam memenuhi kontrak psikologis karyawan dapat menimbulkan adanya keterikatan antara karyawan dengan organisasinya sehingga karyawan tidak mempunyai niatan untuk berhenti dari pekerjaannya (Turnley dan Feldman, 2000). Oleh karena itu, untuk menguji keefektifan kontrak psikologis suatu organisasi, maka perlu untuk menguji pengaruhnya pada work related outcome, yang pada penelitian ini akan berfokus pada intensi keluar karyawan.

Intensi keluar adalah kecenderungan atau niat karyawan untuk berhenti bekerja dari pekerjaannya secara sukarela atas dasar pilihannya sendiri (Wickramasinghe dan Wickramasinghe, 2011). Robinson dan Rosseau (1994) pada hasil penelitiannya melaporkan bahwa tidak terpenuhinya kontrak psikologis berpengaruh pada intensi keluar karyawan dari organisasi. Kim dan Stoner (2008) berpendapat bahwa intensi keluar penting untuk diteliti karena berdampak pada kualitas, konsistensi, dan stabilitas dari karyawan. Selain itu menjadi masalah keuangan bagi organisasi (Kim dan Stoner, 2008)

Ketika kontrak psikologis tidak tepenuhi, karyawan percaya bahwa ada perbedaan antara apa yang dijanjikan dan apa yang dilakukan oleh organisasi (Morrison dan Robinson, 1997; Rosseau, 1995). Perbedaan tersebut menyebabkan adanya ketidakseimbangan hubungan pertukaran antara karyawan dan organisasinya. Oleh karena itu, dalam rangka mengembalikan keseimbangan hubungan pertukaran, karyawan cenderung berkontribusi lebih sedikit untuk organisasi dalam hal kinerja (Turnley dan Feldman,1999). Jika tidak dilakukan pencegahan dalam tahap ketidakseimbangan ini maka karyawan cenderung mencari alternatif pekerjaan baru.

Konsep yang tak kalah penting terkait dengan kontrak psikologis dan intensi keluar adalah komitmen organisasional. Konsep ini didasarkan pada landasan bahwa ketika terjadi pelanggaran kontrak psikologis, karyawan percaya bahwa ada perbedaan antara apa yang dijanjikan dengan apa yang disampaikan oleh organisasi (Morrison dan Robinson, 1997). Adanya pelanggaran kontrak dari organisasi tersebut akan memengaruhisikap dari karyawan yakni kecenderungan untuk mengurangi komitmen mereka terhadap organisasi (Turnley dan Feldman, 1999). Komitmen yang berkurang tersebut akan berdampak pada intensi karyawan untuk keluar dari organisasi.

Selain itu, argumentasi tersebut didasarkan pada teori Affevtive Events Theory oleh Weiss dan Cropanzano (1996). Teori ini mengemukakan bahwa peristiwa di tempat kerja memicu respon emosi karyawan yang mengarah pada sikap dan kemudian perilaku. Pada penelitian ini, kontrak psikologis berperan sebagai stimulus di tempat kerja yang memengaruhi komitmen karyawan. Komitmen karyawan tersebut pada akhirnya memengaruhi perilaku karyawan yang pada penelitian ini diwakili oleh intensi karyawan untuk keluar dari organisasi.

Menurut Allen dan Meyer (1991), terdapat tiga komponen dari komitmen organisasional yaitu komitmen normatif, komitmen afektif dan komitmen kontinuan. Namun, penelitian ini hanya berfokus pada 
komitmen afektif karena komitmen afektif disinyalir sebagai prediktor intensi keluar yang lebih baik dibandingkan dengan jenis komitmen lainnya (Allen dan Meyer, 1997). Komitmen afektif merupakan keterikatan secara emosional yang diidentifikasi dengan keterlibatan karyawan di dalam perusahaan (Allen dan Meyer, 1991). Komitmen afektif yang tinggi dalam diri karyawan dipandang sebagai kunci untuk mempertahankan keanggotaan individu dalam organisasi karena karyawan merasa nyaman, betah, bahagia dan dengan suka rela memberikan kontribusi pada organisasi (Hemdi dan Rahman, 2011). Hal ini tentu menyebabkan seorang karyawan lebih memilih untuk tetap bertahan dalam organisasi daripada mencari alternatif pekerjaan lain. Sehingga, komitmen afektif diindikasikan dapat memediasi pengaruh kontrak psikologis tehadap intensi keluar.

Penelitian ini akan menyasar responden pada industri perhotelan. Pertimbangan ditetapkannya karyawan industri perhotelan sebagai responden karena karyawan pada industri ini memiliki tingkat turnover cukup tinggi dibandingkan karyawan pada industri lain. Berdasarkan survei Badan Pusat Statistik, industri perhotelan di Indonesia mengalami peningkatan pada tahun 2015 tingkat turnover pada industri ini berada pada presentase $21,34 \%$, dan pada tahun 2016 meningkat menjadi 24,00\% (Rosiana, 2017). Sejalan dengan itu, CompData Surveys pada tahun 2014 juga menunjukkan data bahwa persentase turnover pada industri perhotelan mencapai $27,6 \%$ jauh dari persentase turnover pada industri lainnya.

Penelitian Hemdi dan Rahman (2011) sebelumnya telah melaporkan bahwa kontrak psikologis berpengaruh negatif pada intensi keluar dan komitmen afektif memediasi pengaruh kontrak psikologis terhadap intensi keluar pada konteks perhotelan. Namun, penelitian Hemdi dan Rahman (2011) hanya terbatas pada sampel manajer hotel. Hasil penelitian tersebut belum dapat digeneralisasi pada level karyawan. Oleh karena itu, masih membutuhkan studi yang lebih spesifik pada level karyawan sebagai ujung tombak dari industri perhotelan.

Berdasarkan isu yang dibangun tersebut, maka penelitian ini bertujuan sebagai berikut. Pertama, penelitian akan menguji pengaruh (Gambar 1) kontrak psikologis terhadap intensi keluar karyawan. Kedua, penelitian ini akan menguji peranan komitmen afektif sebagai pemediasi atas hubungan kontrak psikologis dan intensi keluar karyawan tersebut. Penelitian dilakukan pada konteks perhotelan berdasarkan pertimbangan tingginya angka turnover karyawan pada industri tersebut.

\section{METODE PENELITIAN}

Data penelitian yang kami gunakan adalah data primer yang diperoleh dari penyebaran kuesioner yang dilakukan dalam rentang waktu dua bulan mulai 22 Maret 2016 hingga 20 Mei 2016. Pengambilan data primer dilakukan pada tujuh hotel yang dapat diakses di wilayah kota Yogyakarta yang diisi langsung oleh karyawan hotel (self administered). Bidang tugas responden terdiri berbagai bidang tugas, yaitu cooking, engineering, front office, operator, housekeeping, HRD, finance, marketing, security, dan waiter. Sebanyak 241 kuesioner disebar peneliti dan yang berhasil dikembalikan sebanyak 230 kuesioner (response rate sebesar 95,43\%). Jumlah kuesioner yang tidak dapat diolah sebanyak 16 kuesioner dengan rincian 6 kuesioner tidak memenuhi syarat minimal masa kerja dan 10 kuesioner tidak diisi lengkap. Dengan demikian, total ada 214 kuesioner yang dapat digunakan dalam penelitian ini.

Sampel pada penelitian ini adalah sebagian dari jumlah total karyawan yang bekerja pada industri perhotelan di kota Yogyakarta. Metode sampel penelitian menggunakan pendekatan purposive sampling method. Metode ini menetapkan bahwa kriteria responden yang digunakan dalam penelitian ini adalah karyawan hotel yang sudah bekerja minimal selama satu tahun. Karyawan yang sudah bekerja minimal selama satu tahun diasumsikan telah memahami pekerjaannya, hambatan dalam bekerja, dan lingkungan kerjanya. Selain itu, karyawan dipandang sudah mengerti dan merasakan perlakuan-perlakuan dari organisasi terhadap dirinya.

Untuk pengujian kualitas instrumen dan data, penelitian ini menggunakan pengujian validitas, yaitu confirmatory factor analysis (CFA) test dan pengujian realibitas yaitu menggunalan Cronbach test (koefisien Alpha). Sedangkan untuk pengujian hipotesis, penelitian ini menggunakan uji regresi berjenjang (hierarchical regression analysis). Ditambahkan pula, penelitain ini akan menyajikan statistik deskriptif untuk mendapatkan informasi besaran rerata dan standar penyimpangan masing-masing skor variabel tersebut. 
Variabel pertama yakni intensi keluar diukur dengan menggunakan tiga item pernyataan yang dikembangkan oleh Mobley et al. (1978). Contoh pernyatan variabel intensi keluar adalah "Saya sering berpikir untuk berhenti dari pekerjaan ini". Item pertanyaan dinilai menggunakan skala Likert lima poin dengan keterangan $1=$ sangat tidak setuju hingga $5=$ sangat setuju. Variabel kedua, komitmen afektif diukur dengan delapan item pernyataan yang disusun berdasarkan dimensi komitmen afekif yang dikembangkan oleh Allen dan Meyer (1990). Semua item pertanyaan dinilai menggunakan skala Likert lima poin, mulai dari $1=$ sangat tidak setuju hingga $5=$ sangat setuju. Variabel ketiga, kontrak psikologis diukur dengan menggunakan 19 item yang dikembangkan oleh De Vos et al. (2003). Pertanyaan disusun dengan lima alternatif skala jawaban mulai dari menerima sangat banyak dari yang telah dijanjikan perusahaan hingga menerima sangat sedikit dari yang telah dijanjikan perusahaan.

Berdasarkan Gambar 1, penelitian akan menguji 2 (dua) hipotesis. Hipotesis pertama (H1) adalah pengaruh negatif kontrak psikologis terhadap intensi keluar. Hipotesis pertama ini dibangun berdasarkan teori pertukaran sosial (Blau dalam Zhao et al., 2007) yaitu ketika karyawan memersepsikan meningkatnya realiasasi perjanjiannya dengan pihak perusahaan (kontrak psikologis), karyawan akan memberikan respon menurunkan intensi keluar atau niat untuk berhenti bekerja (Raja et al. 2004 dan Suazo et al. 2005). Hipotesis kedua (H2) adalah menguji komitmen afektif sebagai pemediasi hubungan antara kontrak psikologis dan intensi keluar tersebut. Pada hipotesis kedua, ketika kontrak psikologis karyawan terpenuhi, maka akan muncul respon psikologis positif yaitu meningkatknya keterikatan dan keterlibatan emosional seseorang karyawan pada organisasinya (komitmen afektif). Hal ini tentu akan menyebabkan seorang karyawan lebih memilih untuk tetap bertahan dalam organisasi atau menurunkan tingkat intensi keluar. Sehingga, komitmen afektif dapat berperan dalam memediasi pengaruh kontrak psikologis tehadap intensi keluar.

\section{HASIL}

Responden penelitian saat ini tercatat sebanyak 214 orang dengan rincian $64,95 \%$ berjenis kelamin lakilaki dan sisanya $35,05 \%$ adalah perempuan. Usia responden didominasi oleh kelompok dengan rentang usia 16-25 tahun sebesar $41,12 \%$. Tingkat pendidikan responden mayoritas berjenjang SMA/sederajat dengan persentase 67,28. Mayoritas responden telah bekerja selama rentang 1-3 tahun, yakni sebesar 53,73\%.

\section{Uji Validitas dan Reliabilitas}

Studi ini menggunakan confirmatory factor analysis (CFA) dengan metode varimax rotation dalam melakukan uji validitas. Kriteria yang digunakan untuk menentukan validnya suatu item pernyataan adalah nilai factor loading lebih besar dari 0,50. Sebelum melakukan uji validitas, terdapat syarat lain yang harus dipenuhi, yaitu KMO (Keiser-Meyer-Olkin) $>0,5$ dan nilai Bartlett's test memiliki signifikansi $<0,05$ (Hair et al. 2014). Nilai KMO dilaporkan sebesar 0,806 dengan nilai signifikansi Bartlett's test adalah 0,000. Terpenuhinya nilai KMO dan Bartlett's test tersebut, maka dapat dilakukan uji validitas lebih lanjut. Hasil uji validitas melaporkan terdapat 9 item yang tidak memenuhi syarat nilai factor loading dari total 30 item yang diuji. Item-item tersebut diantaranya tiga item dari variabel komitmen afektif dan enam item dari variabel kontrak psikologis. Secara keseluruhan, pengujian faktor analisis dilakukan sebanyak dua putaran.

Analisis reliabilitas dilakukan pada item komitmen afektif, intensi keluar, dan kontrak psikologis. Dari hasil uji reliabilitas ketiga variabel dilaporkan memiliki nilai koefisien Alpha Cronbach komitmen afektif sebesar 0,707; intensi keluar sebesar 0,896; dan kontrak psikologis sebesar 0,919 . Hasil tersebut menunjukkan bahwa ketiga variabel dalam penelitian ini memiliki reliabilitas dengan kategori baik (Hair et al. 2014).

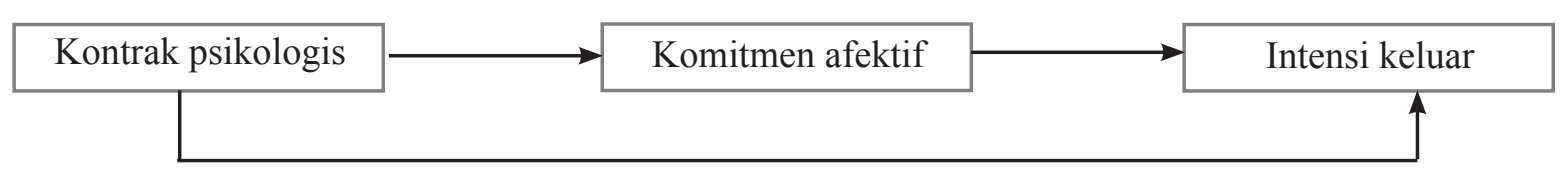

Gambar 1. Kerangka pemikiran penelitian 


\section{Uji Deskriptif dan Korelasi}

Tabel 1 melaporkan hasil statistik deskriptif yakni deskripsi data berupa nilai rata-rata (mean), standar deviasi, dan koefisien korelasi antar variabel dalam penelitian. Berdasarkan Tabel 1, nilai rata-rata komitmen afektif dan kontrak psikologis melaporkan respon yang cukup tinggi dari responden dengan nilai masing-masing 3,631 dan 3,397. Sementara itu, nilai rata-rata intensi keluar dilaporkan memiliki respon yang rendah dari responden dengan nilai 2,844. Adapun nilai standar deviasi variabel komitmen afektif dilaporkan 0,504, variabel kontrak psikologis sebesar 0,212, dan variabel intensi keluar sebesar 0,481. Selain itu, Tabel 1 juga melaporkan hasil korelasi antar variabel yang diteliti. Nilai korelasi cukup kuat dilaporkan terjadi antara variabel komitmen afektif dengan intensi keluar $(\mathrm{r}=0,650)$, nilaikorelasi antara variabel kontrak psikologis dengan intensi keluar dilaporkan cukup $(\mathrm{r}=0,422)$, dan korelasi variabel kontrak psikologis dengan komitmen afektif dilaporkan cukup lemah $(\mathrm{r}=0,222)$.

\section{Uji Regresi}

Pengujian model dalam penelitian ini menggunakan metode analisis regresi berjenjang (hierarchical regression analysis) dengan menggunakan bantuan software SPSS. Analisis data terdiri dari metode regresi sederhana dan metode regresi berganda. Metode regresi sederhana digunakan untuk menguji model regresi kontrak psikologis terhadap intensi keluar (H1). Sedangkan, metode regresi berganda akan digunakan untuk menguji peran pemediasian komitmen afektif pada pengaruh kontrak psikologis terhadap intensi keluar (H2). Tabel 2 menunjukkan hasil pengujian hipotesis 1 dan hipotesis 2 .

\section{Pengaruh Kontrak Psikologis terhadap Intensi Keluar}

Dalam teori pertukaran sosial yang dipaparkan oleh Blau dalam Zhao et al. (2007), hubungan antara karyawan dan perusahaan dibangun berdasarkan teori pertukaran sosial. Karyawan yang memersepsikan pelanggaran perjanjian oleh pihak perusahaan, karyawan akan memberikan respon dengan berperilaku negatif yang dapat memberikan kerugian pada perusahaan.

Salah satu sikap dan perilaku negatif di tempat kerja yang berhubungan dengan kontrak psikologis adalah intensi keluar atau niat untuk berhenti bekerja. Hubungan antara kedua aspek ini pernah diteliti oleh Suazo et al.(2005) yang menemukan hubungan negatif antara kontrak psikologis dengan intensi keluar. Arshad (2016) juga menguatkan bahwa pelanggaran kontrak psikologis berpengaruh positif terhadap intensi keluar.

Teori pertukaran sosial menjelaskan bahwa para pihak dalam suatu hubungan pertukaran menyediakan manfaat satu sama lain dalam bentuk manfaat yang nyata seperti uang atau manfaat yang tidak berwujud seperti dukungan sosial (Suazo et al. 2005). Ketika kontrak psikologis tidak terpenuhi, karyawan percaya bahwa ada perbedaan antara apa yang dijanjikan dan apa yang disampaikan oleh organisasi (Rosseau, 1995; Morrison dan Robinson, 1997). Perbedaan merupakan ketidakseimbangan hubungan pertukaran di bidang sosial antara karyawan dan atasan. Kemudian dalam rangka mengembalikan keseimbanganhubunganpertukaran,karyawancenderung berkontribusi lebih sedikit untuk organisasi dalam hal kinerja (Turnley dan Feldman, 1999). Jika pada tahap ketidakseimbangan ini tidak dilakukan pencegahan, maka pada tahap selanjutnya karyawan akan mencari alternatif pekerjaan baru yang dapat membuka jalan untuk terjadinya perputaran karyawan yang sebenarnya. Semakin terpenuhinya kontrak psikologis karyawan menimbulkan persepsi positif yang menyebabkan mereka senang dan bangga menjadi bagian dari organisasinya sehingga dapat mengurangi intensi keluar. Collins (2010) dalam hasil penelitiannya mengungkapkan bahwa pemenuhan kontrak psikologis perusahaan merupakan prediktor kuat intensi keluar. Berdasarkan hasil analisis tersebut maka peneliti mengajukan hipotesis pertama, yakni sebagai berikut:

$\mathrm{H}-1$ : Pemenuhan kontrak psikologis berpengaruh negatif terhadap intensi keluar karyawan

Hasil uji hipotesis yang tercantum pada Tabel 2 (tahap 1) dapat diidentifikasi bahwa variabel kontrak psikologis berpengaruh negatif dan signifikan terhadap variabel intensi keluar $(\beta=-0,422 ; \mathrm{t}=-6,772 ; \mathrm{p}<0,05)$. Hal tersebut menandakan bahwa, hasil pengujian terhadap hipotesis pertama didukung. Berdasarkan hasil pengujian hipotesis pertama dapat disimpulkan bahwa semakin tinggi tingkat pemenuhan kontrak psikologis yang dialami oleh karyawan hotel, maka niat untuk meninggalkan pekerjaan akan semakin rendah. Hasil analisis regresi juga menunjukkan nilai adjusted R square sebesar 0,174. Hal tersebut menandakan bahwa sebesar 17,4\% variansi variabel intensi keluar dapat dijelaskan oleh variabel kontrak psikologis. 
Tabel 1. Statistik Deskriptif

\begin{tabular}{lccccc}
\hline \multirow{2}{*}{ Variabel } & \multirow{2}{*}{ Rata-rata } & Standar Deviasi & \multicolumn{3}{c}{ Nilai Korelasi } \\
\cline { 4 - 6 } & & & Komitmen Afektif & Kontrak Psikologis & Intensi Keluar \\
\hline Komitmen Afektif & 3,631 & 0,504 & 1 & $0,222^{* *}$ & $0,650^{* *}$ \\
Kontrak Psikologis & 3,397 & 0,212 & $0,222^{* *}$ & 1 & $0,422^{* *}$ \\
Intensi Keluar & 2,844 & 0,481 & $0,650^{* *}$ & $0,422^{* *}$ & 1 \\
\hline
\end{tabular}

** Korelasi signifikan pada level 0,05 (2-tailed)

Tabel 2. Hasil Uji Regresi Hipotesis 1 dan Hipotesis 2

\begin{tabular}{|c|c|c|c|c|}
\hline \multicolumn{5}{|c|}{ Hasil Regresi Kontrak Psikologis terhadap Intensi Keluar (Tahap 1) } \\
\hline Variabel & Standardized Coefficient $(\beta)$ & Nilai t & Nilai $\mathrm{p}$ & Keterangan \\
\hline Kontrak Psikologis & $-0,422$ & $-6,772$ & 0,000 & Signifikan \\
\hline $\begin{array}{l}\text { Nilai adjusted } \mathrm{R} \text { squ } \\
\text { Nilai } \mathrm{F}=45,853 \\
\text { Nilai Sig. }=0,000\end{array}$ & & & & \\
\hline \multicolumn{5}{|c|}{ Hasil Regresi Kontrak Psikologis terhadap Komitmen Afektif (Tahap 2) } \\
\hline Variabel & Standardized Coefficient $(\beta)$ & Nilai t & Nilai $\mathrm{p}$ & Keterangan \\
\hline Kontrak Psikologis & 0,222 & 3,309 & 0,001 & Signifikan \\
\hline $\begin{array}{l}\text { Nilai adjusted } \mathrm{R} \text { squ } \\
\text { Nilai } \mathrm{F}=10,949 \\
\text { Nilai Sig. }=0,001\end{array}$ & & & & \\
\hline \multicolumn{5}{|c|}{ Hasil Regresi Komitmen Afektif terhadap Intensi Keluar (Tahap 3) } \\
\hline Variabel & Standardized Coefficient $(\beta)$ & Nilai $\mathrm{t}$ & Nilai $\mathrm{p}$ & Keterangan \\
\hline Komitmen Afektif & $-0,650$ & $-12,468$ & 0,000 & Signifikan \\
\hline $\begin{array}{l}\text { Nilai adjusted } \mathrm{R} \text { squ } \\
\text { Nilai } \mathrm{F}=155,442 \\
\text { Nilai Sig. }=0,000\end{array}$ & & & & \\
\hline \multicolumn{5}{|c|}{ Hasil Regresi Kontrak Psikologis dan Komitmen Afektif terhadap Intensi Keluar (Tahap 4) } \\
\hline Variabel & Standardized Coefficient $(\beta)$ & Nilai t & Nilai $p$ & Keterangan \\
\hline Kontrak Psikologis & $-0,292$ & $-5,871$ & 0,000 & Signifikan \\
\hline Komitmen Afektif & $-0,568$ & $-11,781$ & 0,000 & Signifikan \\
\hline $\begin{array}{l}\text { Nilai adjusted } \mathrm{R} \text { squ } \\
\text { Nilai } \mathrm{F}=107,226 \\
\text { Nilai Sig. }=0,000\end{array}$ & & & & \\
\hline
\end{tabular}

Hasil tersebut, sesuai dengan teori dan penelitian empiris sebelumnya (Robinson dan Rosseau, 1994; Suazo et al.2005; Arshad, 2016). Kebijakan manajemen hotel terkait pemenuhan kontrak psikologis memengaruhi ada atau tidaknya niat karyawan untuk meninggalkan hotel tempat mereka bekerja yang selanjutnya lebih dikenal dengan intensi keluar. Semakin tinggi tingkat kontrak psikologis karyawan yang dapat terealisasikan, maka semakin rendah intensi keluar yang dirasakan karyawan. Ketidakpastian yang dirasakan individu akan berkurang pada saat karyawan merasa kontrak psikologisnya terpenuhi. Karyawan akan merasa aman dan nyaman di dalam lingkungan kerja ketika organisasi dapat memberikan kondisi kerja yang disetujui/ disepakati bersama. Rasa nyaman ini yang pada akhirnya membuat karyawan cenderung mempertimbangkan untuk tidak meninggalkan organisasinya atau dengan kata lain intensi keluar tidak terbentuk di dalam benak karyawan. Oleh karena itu, pemenuhan kontrak psikologis karyawan perlu diperhatikan sebagai upaya organisasi dalam meminimalisir munculnya intensi keluar yang dapat dirasakan oleh anggota organisasi.

\section{Peran Komitmen Afektif sebagai Pemediasi dalam Pengaruh Kontrak Psikologis terhadap Intensi Keluar}

Allen dan Meyer (1990) mendefinisikan komitmen afektif sebagai keterikatan secara emosional yang diidentifikasi dengan keterlibatan karyawan di dalam perusahaan. Komitmen afektif terbentuk melalui proses panjang yang berawal dari harapan seorang karyawan 
untuk terus bekerja pada organisasi yang menawarkan lingkungan kerja dan pengalaman kerja positif. Apabila karyawan telah mendapatkan lingkungan kerja dan pengalaman kerja yang ia inginkan dalam suatu organisasi, maka untuk tetap berada pada organisasi tersebut, ia akan berusaha memberikan kontribusi pada organisasinya. Karyawan dengan komitmen afektif yang kuat akan terus bekerja pada suatu perusahaan karena ia menginginkannya.

Vandenberghe et al. (2004) menyatakan bahwa komitmen afektif akan berpengaruh langsung dan mempunyai hubungan yang negatif dan signifikan terhadap intensi keluar. Ketika kontrak psikologis karyawan terpenuhi, karyawan percaya bahwa apa yang dijanjikan organisasi ternyata sesuai dengan apa yang disampaikan sebelumnya (Morrison dan Robinson, 1997).

Respon psikologis positif menimbulkan rasa aman dan nyaman saat bekerja. Rasa aman dan nyaman yang ditimbulkan karena terpenuhinya kontrak psikologis selanjutnya menimbulkan keterikatan dan keterlibatan emosional seseorang karyawan pada organisasinya atau yang lebih dikenal dengan komitmen afektif. Hal ini tentu akan menyebabkan seorang karyawan lebih memilih untuk tetap bertahan dalam organisasi daripada mencari alternatif pekerjaan lain. Sehingga, komitmen afektif dapat berperan dalam memediasi pengaruh kontrak psikologis tehadap intensi keluar.

Menurut affective event theory hubungan antara kontrak psikologis (stimulus) dan intensi keluar (perilaku) tidak sederhana, karena membutuhkan variabel penjelas untuk dapat memahami hubungan kontrak psikologis pada intensi keluar (Zhao et al. 2007). Affective event theory menjelaskan bahwa positive work event yang dirasakan oleh karyawan akan berdampak terhadap positive emotional terlebih dahulu sebelum berdampak pada work related outcome. Apabila dikaitkan dengan penelitian ini, maka terpenuhinya kontrak psikologis akan menimbulkan emosi atau sikap positif misalnya komitmen afektif yang selanjutnya dapat menekan intensi keluar yang dirasakan karyawan sebagai konsekuensi perilaku.

Argumentasi tersebut didukung oleh penelitian yang dilakukan oleh Cantisano et al. (2008) bahwa terpenuhinya kontrak psikologis karyawan dapat menjadi indikator bagi karyawan bahwa organisasi mempunyai itikad baik untuk memberikan manfaat sesuai dengan ekspektasinya. Organisasi yang melakukan hal tersebut akan menyebabkan karyawan merasa dihargai atas keberadaan dan kontribusinya dalam organisasi. Perasaan karyawan kemudian menimbulkan pandangan bahwa mereka telah menjadi bagian dalam organisasi, merasa seperti bagian dari keluarga, dan adanya keterikatan secara emosional dengan organisasi. Ketika perasaan itu sudah terbentuk di dalam diri karyawan artinya kontrak psikologis karyawan telah terpenuhi yang kemudian mampu menciptakan komitmen afektif. Selanjutnya komitmen afektif mampu mengurangi keinginan karyawan untuk meninggalkan organisasi sebab karyawan merasa nyaman, betah, dan bahagia bekerja di organisasi serta dengan suka rela akan memberikan kontribusi pada organisasi hingga akhir karirnya tanpa berpikir untuk mencari alternatif pekerjan lain.

Komitmen afektif dalam penelitian ini berperan sebagai variabel pemediasi hubungan antara kontrak psikologis dan intensi keluar. Dimana terbentuknya komitmen afektif diawali dengan terpenuhinya kontrak psikologis karyawan dan akan berdampak pada menurunnya tingkat intensi keluar serta tidak dapat dipisahkan dari peranan kontrak psikologis yang terbentuk sebelumnya (Zhao et al. 2007). Penelitian terdahulu telah melaporkan bahwa kontrak psikologis berpengaruh pada komitmen organisasional (Tawa, 2017). Selain itu, Meyer et al. (2002) melaporkan bahwa komitmen organisasional merupakan prediktor kuat pada intensi keluar. Berdasarkan hasil analisis, berikut merupakan hipotesis kedua dari penelitian ini:

H-2: Komitmen afektif memediasi pengaruh kontrak psikologis terhadap intensi keluar

Hipotesis kedua ini diuji menggunakan tahap-tahap uji mediasi yang dikemukakan oleh Baron dan Kenny (1986). Tabel 2 menunjukkan bahwa pada tahap pertama, hubungan negatif antara kontrak psikologis dan intensi keluar adalah signifikan $(\beta=-0,422 ; \mathrm{t}=$ $6,772 ; p<0,05)$, dengan demikian persyaratan pertama dari Baron dan Kenny (1986) terpenuhi. Tahap kedua menunjukkan bahwa variabel kontrak psikologis berpengaruh positif dan signifikan terhadap variabel komitmen afektif $(\beta=0,222 ; \mathrm{t}=3,309 ; \mathrm{p}<0,05)$, dengan demikian persyaratan kedua dari Baron dan Kenny (1986) terpenuhi. Tahap 2 menunjukkan bahwa variabel komitmen afektif berpengaruh negatif dan signifikan terhadap variabel intensi keluar $(\beta=-0,650$; $\mathrm{t}=-12,468 ; \mathrm{p}<0,05)$. 
Hal tersebut menandakan bahwa, persyaratan ketiga dari hubungan mediasi juga terpenuhi. Pada tahap keempat, pengaruh variabel kontrak psikologis masih tetap signifikan $(\beta=-0,292 ; \mathrm{t}=-11,7831 ; \mathrm{p}<0,05)$ terhadap intensi keluar. Hasil ini menunjukkan nilai koefisien beta lebih kecil dibandingkan hasil nilai beta pada tahap pertama yakni $-0,422$. Maka dapat disimpulkan bahwa peran komitmen afektif dalam pengaruh kontrak psikologis terhadap intensi keluar memediasi secara parsial. Artinya, bahwa variabel independen (kontrak psikologis) masih memiliki pengaruh secara langsung terhadap variabel dependen (intensi keluar).

Hasil penelitian ini didukung oleh ,penelitian Hemdi et al. (2011) yang membuktikan bahwa semakin terpenuhinya kontrak psikologis karyawan menimbulkan persepsi positif yang menyebabkan mereka senang dan dapat meningkatkan dimensi bangga menjadi bagian dari organisasinya. Terpenuhinya kontrak psikologis dapat meningkatkan dimensi emosional, karena dengan memberikan kondisi kerja yang disetujui bersama dapat memberikan keamanan kerja sehingga karyawan akan merasa aman dan nyaman dalam lingkungan kerjanya. Selain itu, terpenuhinya kontrak psikologis juga dapat meningkatkan dimensi loyalitas. Kontrak psikologis yang terpenuhi mampu mengurangi ketidakpastian yang dirasakan karyawan sehingga mereka merasa bahagia bekerja di organisasi tersebut dan dengan suka rela akan memberikan kontribusi pada organisasi hingga akhir karirnya. Hal ini pada akhirnya menyebabkan seorang karyawan lebih memilih untuk tetap bertahan dalam organisasi daripada mencari alternatif pekerjaan lain atau dengan kata lain dapat mengurangi intensi keluar karyawan.

\section{Implikasi Manajerial}

Penelitian memberi implikasi manajerial bahwa upaya mencegah peningkatan perputaran keluar-masuk karyawan, khususnya di industri perhotelan saat ini dapat dimulai dengan berkomitmen pada pemenuhan perjanjian kerja (kontrak psikologis) dengan karyawan. Kontrak psikologis ini dapat terpenuhi dengan memerhatikan manfaat terkait peluang pengembangan karir, konten pekerjaan, iklim sosial, imbalan finansial serta keseimbangan kehidupan pribadi dan pekerjaan.

\section{KESIMPULAN DAN SARAN}

\section{Kesimpulan}

Hasil penelitian ini menunjukkan bahwa kontrak psikologis memiliki pengaruh negatif dan signifikan terhadap intensi keluar. Selain itu, hasil penelitian ini juga menunjukkan bahwa komitmen afektif memiliki peran sebagai variabel pemediasi.

\section{Saran}

Saran pengembangan penelitian selanjutnya adalah melibatkan karyawan di berbagai industri, misalnya bank, rumah sakit, telekomunikasi dan manufaktur. Dengan demikian, dapat diperoleh komparasi hasil penelitian dari responden pada lingkungan yang berbeda atau generalisai hasil yang lebih luas. Selanjutnya, penelitian selanjutnya dapat menguji lebih detail dimensi-dimensi variabel komitmen organisasional lainnya yakni komitmen normatif dan komitmen kontinu sebagai pemediasi. Variabel kontrak psikologis juga dapat dispesifikkan pada dimensi transaksional dan relasional. Hal ini bertujuan agar hasil penelitian lebih komperhensif.

\section{DAFTAR PUSTAKA}

Allen NJ, Meyer JP. 1990. The measurement and antecedents of affective, continuan and normative commitment to the organization. Journal of Occupational Psychology 63: 1-18. https://doi. org/10.1111/j.2044-8325.1990.tb00506.x.

Allen NJ, Meyer JP. 1991. A three-component conceptualization of organizational commitment. Human Resource Management Review 1(1): 61-89. https://doi.org/10.1016/10534822(91)90011-Z.

Allen NJ, Meyer JP. 1997. Commitment in the Workplace: Theory, Research, and Application. Thousand Oaks, CA : Sage.

Arshad R. 2016. Psychological contract violation and turnover intention: do cultural values matter? Journal of Managerial Psychology 31:251-264. https://doi.org/10.1108/JMP-10-2013-0337.

Baron RM, Kenny DA. 1986. The moderator-mediator variable distinction in social psycholgical research: conceptual, strategic, and statistical consideration. Journal of Personality and Social Psycholgy 51: 1173-1182. https://doi. 
org/10.1037/0022-3514.51.6.1173.

Cantisano GT, Dominguez JFM, Depolo M. 2008. Psycological contract breach and outcomes: combining meta-analysis and structural equation model. Psychotema 20(3): 487-496.

Collins MD. 2010. The effect of psychological contract fulfillment on manager turnover intentions and its role as a mediator in a casual, limited-service restaurant environment. International Journal of Hospitality Management 29: 736-742. https:// doi.org/10.1016/j.ijhm.2010.03.005.

CompData Surveys. 2014. Turnover Rates by Industry. Compensationforce.com. http:// www.compensationforce.com/2015/03/2014turnover-rates-by-industry.html. $\left[\begin{array}{ll}6 & \text { Januari }\end{array}\right.$ 2015].

De Vos A, Buyens D, Schalk R. 2003. Psychological contract development during organizational socialization: adaption to reality and the role of reciprocity. Journal of Organizational Behavior 24: 537-559. https://doi.org/10.1002/job.205.

Guest D, Conway N. 2005. Public and Private Sector Perspective on the Psychological Contract: result of the 2005 CIPD Survey. Chartered Institute of Personnel and Development, London.

Hair JF, Black WC, Babin BJ, Anderson RE. 2014. Multivariate Data Analysis (7ed). Edinburgh Gate: Pearson Education Limited.

Hemdi MA, Rahman NA. 2011. Turnover of hotel managers: addressing the effect of psychological contract and affective commitment. International Journal of Bussiness and Social Science.World Applied Science 23 : 76-88.

Kim H, Stoner M. 2008. Burnout and turnover intention among social workers: effects of role stress, job autonomy and social support. Journal Administration in Social Work 32: 5-25. https:// doi.org/10.1080/03643100801922357.

Meyer JP, Stanley DJ, Herscovith L, Topolntsky L. 2002. Affective, continuance and normative commitment to the organization: a meta-analysis of antecedents, correlates, and consequences. Journal of Vocational Behavior 61: 20-52. https://doi.org/10.1006/jvbe.2001.1842.

Mobley WH, Horner SO, Hollingsworth AT.1978. An evaluation of precursors of hospital employee turnover. Journal of Applies Psychology 63: 408-414. https://doi.org/10.1037/00219010.63.4.408.

MorrisonEW, Robinson SL. 1997. When employees feel betrayed: a model of how psychological contract violation develops. Academy of Management Review 22(1): 226-256. https://doi.org/10.5465/ amr.1997.9707180265.

Robinson SL, Rousseau DM. 1994. Breaching the psychological contract: not the exception but the norm. Journal of Organizational Behavior 15: 245-259. https://doi.org/10.1002/ job.4030150306.

Rosiana N. 2017. Statistik Mobilitas Penduduk dan Tenaga Kerja 2017. https://www.bps.go.id/publ ication/2017/12/25/2017000000000000102366/ statistik-mobilitas-penduduk-dan-tenaga-kerja2017.html [21 Maret 2017].

Rousseau DM. 1995. Psychological Contract in Organizations: Understanding Written and Unwritten Agreements. Thousand Oaks, CA : Sage.

Suazo MM, Turnley WH, Mai-Dalton RR. 2005. The role of perceived violation in determining employees reactions to psychological contract breach. Journal of Leadership and Organizational Studies 12(1): 24-36. https://doi. org/10.1177/107179190501200104.

Suazo MM. 2009. The mediating role of psychological contract violation on the relations between psychological contract breach and work related attitudes and behaviors. Journal of Managerial Psychology 24(2): 136-160. https://doi. org/10.1108/02683940910928856.

Turnley WH, Feldman DC. 1999. Psychological contract violations on exit, voice, loyalty, and neglect. Human Relations 52(7): 895-922. https://doi.org/10.1177/001872679905200703.

Turnley WH, Feldman DC. 2000. Re-examining the effect of Psychological contract violations: unmet expectation and job satisfaction as mediators. Journal of Organizational Behavior 21: 25-42. https://doi.org/10.1002/(SICI)10991379(200002)21:1<25::AID-JOB2>3.0.CO;2-Z. Vandenberghe C, Bentein K, Stinglhamber F. 2004. Affective commitment to the organization, supervisor, and workgroup: antecedents and outcomes. Journal of Vocational Behavior 64:47-71.https://doi.org/10.1016/S00018791(03)00029-0.

Weiss HM, Cropanzano R. 1996. Affective events theory: a theoretical discussion of the structure, causes and consequences of affective experiences at work. Research in Organizational Behavior 18: $1-74$.

Wickramasinghe D, Wickramasinghe V.2011. Perceived 
organizational support, job involvement and turnover intention in lean production in Sri Lanka. International Journal Adv Manufacture Technology 55:817-810.https://doi.org/10.1007/ s00170-010-3099-z.
Zhao H, Wayne SJ, Glibkowski BC, Bravo J. 2007. The impact of psychological contract breach on work-related outcomes: a meta analysis. Personnel Psychology 60: 647-680. https://doi. org/10.1111/j.1744-6570.2007.00087.x. 